\title{
CREATIVE WORK UNDER COGNITIVE CAPITALISM CONDITIONS
}

\author{
Viktor Barhatov $^{1}$, Yuner Kapkaev², Oleg Dyachenko ${ }^{3}$
}

\begin{abstract}
The transformation of production relations, which we have all witnessed during the last 20 years, has shown outdated existing theoretical approaches toward an understanding of the economy. The search for alternative ways of the economic development involves representatives of various scientific fields: post industrialism, information economy, sustainable economic development, new economy and others. Of particular interest is the concept of cognitive capitalism, which allows us to consider the transformation occurring "inside" of capitalism. This article proposes an approach to the study of the cognitive capitalism nature from the perspective of the Marxian theory, productive forces of society, and psychology. Methodological framework used has revealed contradictions of existing liberal-capitalist vector of development and the innovation-oriented economic formation. This is based on the exploitation of economic agent's creative work. The technique, which allows us to assess the involvement of management in cognitive capitalism, is provided.
\end{abstract}

JEL Classification Numbers: O 100, P 590, DOI: http://dx.doi.org/10.12955/cbup.v2.462

Keywords: cognitive capitalism, creativity, creative thinking, labor, non-material production, intellectual production, ideas, creative potential

\section{Introduction}

At the present stage of development, the manufacturing process is rarely identified as physical, hard manual labor; mostly, it is a process of self-reproduction, production of internal human intellectual potentials or cognitive production. The establishment of new production relations does not overcome material production. On the contrary, the intellectual (non-material) and material production are interdependent-forming a single high-tech process of social production. Often we see that in most innovative market economies, more material production is integrated with non-material production based on new scientific knowledge and ideas. Thus, the rates of socio-economic development of the country are higher.

\section{Literature review}

At the end of the $20^{\text {th }}$ century, various scientists from Europe and the United States introduced, in different variations, the category of "cognitive capitalism." Among these scientists, the works of Boutang (2007), Burton (1999), Florida (2002), Fumagalli (2007), Gorz (2003), Murrau (2010), Procopio (1999), Rossiter (2006), Rullani (2004), and Vercellone (2007) should be noted. It is emphasized in this category that the modern period is identified as capitalism transformation, where the cognitive component acts as a destructive element of basics and principles of the capitalist mode of production.

The central economic category in the study of cognitive capitalism is its special forms of cultural production-intellectual, rational and creative way to produce non-material goods.

When regarding the creative work in the field of cultural production, it is necessary to replace the category of "art" or "creativity." Since the whole process of knowledge (non-economic product) and ideas (economic product) generation basis occurs without the use of material, technological means, i.e. in the human mind, one should start the scientific search for the nature of creativity in psychological science. Thus, the human creativity is understood as the ability to generate unusual ideas to find original solutions, and to deviate from the traditional patterns of thought. In the middle of the $20^{\text {th }}$ century, American psychologist, J. Guilford, developed a model of the structure of human

\footnotetext{
${ }^{1}$ Viktor Barhatov, Chelyabinsk State University, Russian Federation, ieo-science@csu.ru

${ }^{2}$ Yuner Kapkaev, Chelyabinsk State University, Russian Federation, zam@csu.ru

${ }^{3}$ Oleg Dyachenko, Chelyabinsk State University, Russian Federation, dyachenko@csu.ru
} 
intelligence, i.e. his cognitive abilities, where he highlighted the divergent (creative) and convergent (intellectual and rational) ways of thinking. Under the cognitive way of thinking, we understand linear, logical thinking strategy based on the use of previously learned algorithms, assuming only the correct solution to the problem when there are many conditions to consider. Under divergent (from Latin word "Divergere," which means "to diverge") multi-directional thinking, non-linear thinking strategy based on finding the set of solutions of the same problem, i.e. characterized by the rejection of formulaic solutions of the problem, is understood. In this case, it is clear that psychological science is separated from the creative intellectual abilities. For economic science, such division also has a fundamental meaning.

\section{Data and methodology}

These two forms of thinking should be attributed to the elements of cultural production, which are the basis of non-material production. Intellectual production is the various cognitive abilities of people to the processing of available information and knowledge. An overall block diagram of non-material production is illustrated in Figure 1.

Intellectual production is a specific mental-based human activity on consumption of accumulated knowledge reservoir, in order to create new knowledge and ideas. Material production is different from the intellectual in that firstly, it embodies the accumulated knowledge and ideas in material carrier; and secondly, the creation of the benefit is mediated by the use of technical tools.

Under cognitive divergent production, we understand the form of the intellectual production process for the creation of ideas, values, theories, and images, based on irrational logic. The need to separate human abilities to process information, generate new knowledge, and make management decisions is caused by global economic trends in the world. The model of an "intelligent person" is not quite adequate to the existing conditions; we are still unable to provide a platform to prepare a young person for rapidly changing, turbulent economic and technological trends. This is confirmed by the fact that the modern student entering the labor market is no longer suitable for acquisitive work, as competency and knowledge obtained from the University are obsolete. Moreover, the most progressive corporations today are already fighting not for an "all-knowing” expert, but for an extraordinarily creative professional who is capable of creating innovations, which were previously non-existent.

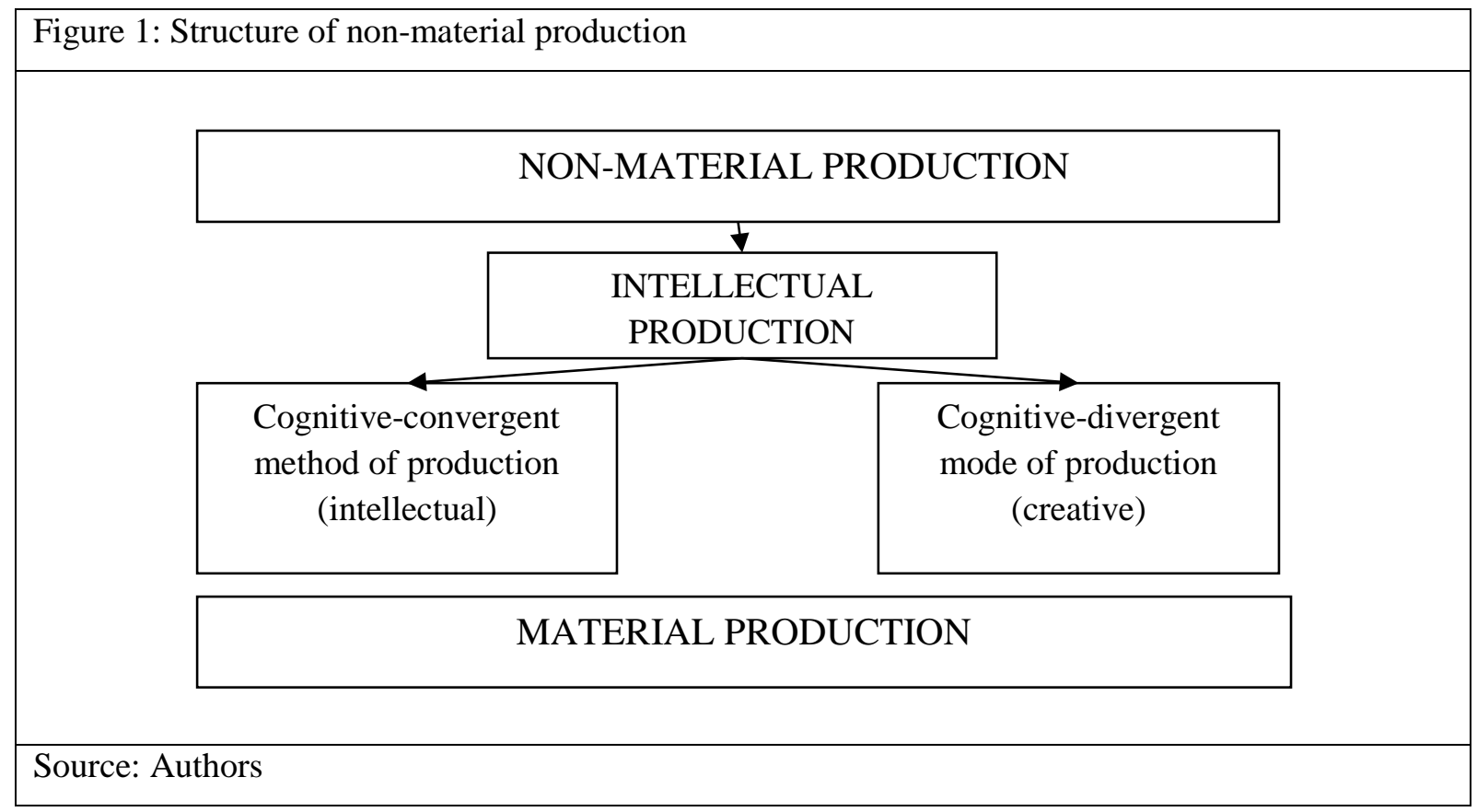




\section{Results and discussion}

High-tech, innovative (financial) economic development, to a certain extent, does not depend on the intellectual as much as on creative abilities of employees. This can be explained by many experts from various fields of knowledge. Thus, $M$. Tring states, "the creative essence of the invention is a new design principle that cannot be obtained from the known ideas through inference (convergent cognitive or intellectual thought).” An important feature of a divergent type of production is its irrationality, illogicality or more properly known, in modern conditions, as a new type of rationality.

Experts stated that novations did not appear on the basis of logical thinking. G. Adams once remarked that purely logical discoveries did not exist. Discoveries occur at an unconscious level, as a kind of flash of ideas after preliminary conscious work. J. P. Piaget (Piaget, 1962) noticed that the entire history of science, from Aristotle's absolutes of Physics to Einstein's relativity theory, suggests that the progress of knowledge never happens by simply adding and requires constant reformulation of previous points of view, but rather a permanent disobjectification and integration with individualized accumulated knowledge.

Thus, the ability of economic agents in processing information and its assimilation, generating of new ideas, and making of management decisions, i.e. creative (divergent) work, in conditions of nonmaterial production becomes of an utmost importance both for management practice and science.

Why should such categories as cognitive capitalism, cognitive and divergent manufacturing ideas be highlighted and studied? It is done so in order to give an explanation as to why there is containment of high-tech development in the domestic economy, with nearly the most enormous resources in human intellectual potential, of the once powerful technological, industrial base,. This contradiction can be explained in the legislation imposed by a myth of the "resource curse," corrupted officials, and disinterest of capitalists to invest and risk their own financial resources. Yet one can look at the other reasons why 28,000 highly qualified scientists cannot create something new, why all-knowing professors working at universities often earn less than a taxi driver, and why goods with a label "Made in Russia" are not in demand. Perhaps we should admit that the once powerful intellectual core of the Soviet economy, which today has "plunged" into the market system, no longer uses its "talents" to create ideas on a global level. Why a professor, whose direct responsibility is to produce ideas, publishes only few articles a year at best, which are no longer referenced or read? Is the reason being that they do not have ideas in them? Why do scientists earn very little? It is because they produce ideas of "low quality." Why is the funding not given? That is because it is unprofitable and risky to invest in projects without ideas. Why do we focus on borrowing? Because it is easier to buy someone else's idea than to invest in creating a favorable environment for those who are able to produce ideas, as it is much more expensive.

Thus, today the economic science should turn its attention to how the non-material goods are produced, in particular the knowledge and ideas, and what conditions affect the method of production.

The scientific literature has accumulated a wealth of information about how to assess the innovation potential of the economy - the ability of the economic system to develop and implement high-tech development. Among conventional methods, international standards of estimation of innovative potential should be allocated. Assessment of innovative capacity of European countries is based on the standards governing the accounting rules of innovation and resource base for such activities, which are written in such documents as "Frascati Manual," “Oslo Manual,” and “Canberra Manual.” Among others, a methodology of European Innovation Scoreboard (EIS) is allocated,to assess the level of development of knowledge, while economic experts from the Institute of the World Bank introduced a Knowledge for Development (K4D) Program. In addition, Florida (2002) input the "creativity index" reflecting the position of a region in creative economy of the U.S., wherein the starting point in the 
research methodology of the creative economy is the idea that the success of the place is determined by the presence and concentration of its creative class.

Based on the above experience of valuation techniques implementation on the level of development of the innovation economy and knowledge economy, the algorithm of comparative assessment of the level of involvement of the economic system in cognitive capitalism was derived.

The calculation method is based on the "Development of divergent cognitive capacity index," which is calculated as the arithmetic mean of several groups of indicators reflecting the development of nonmaterial production from different sides, contributing to the cultivation of a "healthy" post-industrial (super-industrialized) society. These indicators or "blocks" are described as follows:

- Block I: Social Security indicator-manpower basis of innovation and creative economy capable of generating creative ideas, generating scientific knowledge and bringing them to the level of innovation.

- Block II: Educational software indicator-demonstrates a level of development of cognitive and divergent productive forces of society.

- Block III: Scientific support indicator-resource base of innovation and creative potential, including the results achieved in the field of basic scientific research arranged in the form of publications, reflecting divergent activity of society to develop the resources needed in the production process to their further disobjectification, hence, growing of divergentariat. By "divergentariat" (derived from the proletariat), we refer to a sub-class of white collars who makes a living by selling their labor force and is engaged in primarily creative (divergent psychological abilities) activities.

- Block IV: Technological support indicator, reflecting the activity of divergentariat in innovation, being a measure of cost efficiency in research and development, as well as reflecting the official processes of the level of scientific and technological progress.

Figure 2: The calculated index of cognitive and divergent economies potential development in 2012

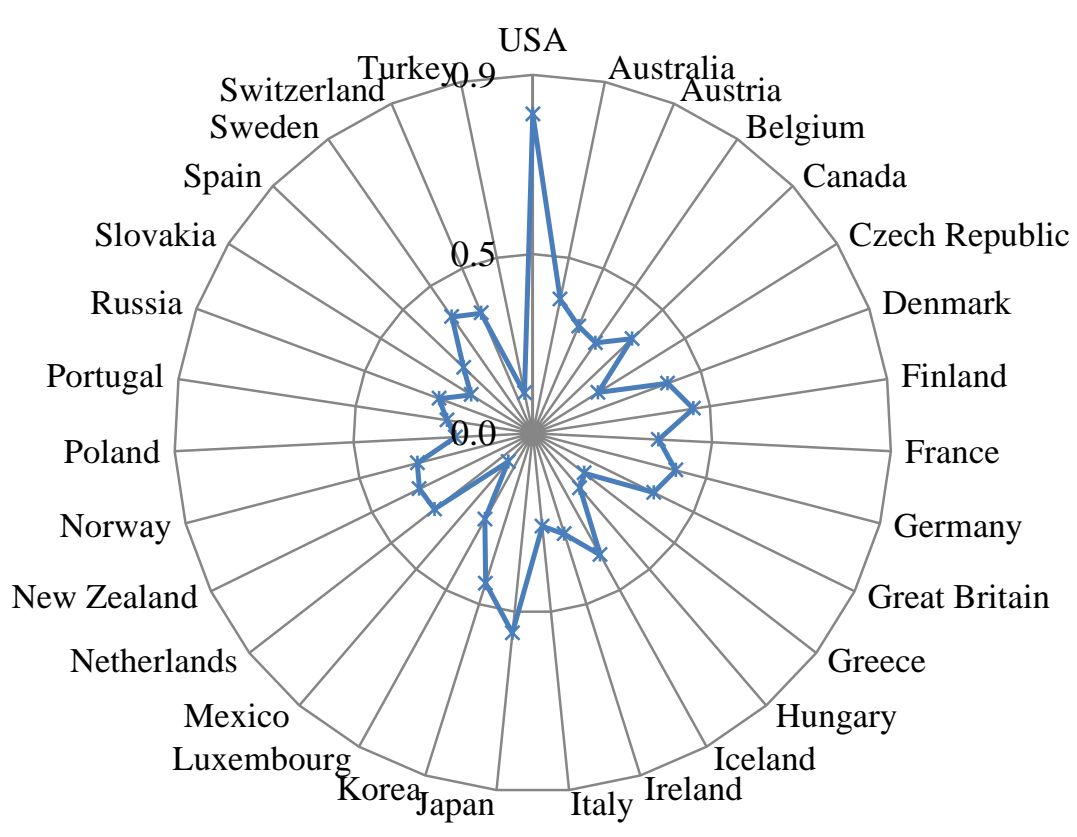

Source: World Development Indicators (2014) and Authors

The proposed assessment methodology allows us to analyze a number of economies in relation to their involvement in cognitive capitalism. Materials published by World Bank, Eurostat, OECD statistics 
(OECD, 2004), as well as other international organizations, were the source of statistics.

Figure 2 shows the calculated index of cognitive and divergent economies potential development in 2012.

The highest development level $\left(I_{\text {cog }}\right)$ is in USA at 0.795; where as Japan lags behind at 0.503; and Germany is only at 0.402 . In Russia, the level of development of innovative and creative economy in 2012 reached 0.271 .

\section{Conclusion}

The deeper and more detailed analysis of the indices included in the indicators and the analysis of exogenous factors (external "creative environment") revealed a number of regularities in the development of cognitive capitalism in various countries. Thus, a low level of involvement in nonmaterial production depends on the productive forces of the society based on production capacity IV of technological structure; great potential for innovative development are in those countries that concentrate on highly specialized professionals. In turn, this accommodation is explained by the fact that people are able to engage in creative work and migrate to regions where industrialized technological system is minimized, due to its succession by technologies of higher, superindustrialized, post-industrial environment. It is also noted that in countries where the high-level of cognitive and divergent development potential were said, there were also higher rates of GDP value.

Application of this methodology is relevant at the present stage of technological development as it allows to us specify those weaknesses in the economic system, which are responsible for the quality of ideas reproduced in society.

\section{Acknowledgement}

The publication was prepared as part of a research project \# 14-18-02508, supported by RSF.

\section{References}

Boutang, Y. M. (2007). Le capitalisme cognitif: la nouvelle grande transformation [Cognitive Capitalism: The New Great Transformation]. Paris: Editions Amsterdam.

Burton, A. -J. (1999). Knowledge Capitalism: Business, Work and Learning in the New Economy. Oxford: University Press. doi:10.1093/acprof:oso/9780198296225.001.0001

Chen, D. C. (2005). The Knowledge Economy, the KAM Methodology and World Bank Operations. World Bank Institute Working Paper, 37256.

Florida, R. (2002). The Rise of the Creative Class. And How It's Transforming Work, Leisure and Everyday Life. Basic Books.

Fumagalli, A. (2007). Bioeconomia e capitalism cognitive [Bioeconomy and Cognitive Capitalism]. Roma: Carocci.

Gorz, A. (2003). L'immateriel. Connaissance, valeur et capital [The Immaterial. Knowledge, Value and Capital]. Paris: Editions Galilee.

Murrau, L. (2010). L'economia della conoscenza e la rivoluzione del capitalismo cognitivo [The Knowledge Economy and the Revolution of Cognitive Capitalism]. Febbraio: Menabo di Eticaed Economia.

OECD (2004). Methodology Report on European Scoreboard. Retrieved from www.trendchart.cordis.lu/scoreboards/ scoreboard2005/index.cfm.

Piaget, J. (1962). Play, Dreams and Imitation in Childhood. New York: Norton

Procopio, L. (1999). Il capitalismo cognitivo e il neoriformismo [Cognitive Capitalism and Neo-Reformism]. Prometeo, V serie. Retrieved from http://www.leftcom.org/it/articles/1999-12-01/il-capitalismo-cognitivo-e-il-neo-riformismo/

Rossiter, N. (2006). Organized Networks: Media Theory, Creative Labour, New Institutions. Rotterdam: NAi Publisher, Institute of Network Cultures.

Rullani, E. (2004). Economia della conoscenza: Creatività e valore nel capitalismo delle reti [Knowledge Economy: Creativity and Value in Capitalism Networks]. Milano: Carocci.

Varcellone, C. (2007). From Formal Subsumption to General Intellect: Elements for a Marxist Reading of the Thesis of Cognitive Capitalism. Historical Materialism, 15(1), 13-33. doi:10.1163/156920607X171681

World Development Indicators (2014). Retrieved from http://data.worldbank.org/data-catalog/world-development-indicators 